\title{
DIREITO, SAÚDE E PROMOÇÃO DA SAÚDE DA MULHER
}

\section{RIGHT, HEALTH AND WOMEN'S HEALTH PROMOTION}

\author{
Maria Eliane Alves de Sousa* \\ Maria de Fátima Lobato Tavares ${ }^{* *}$ \\ Rosa Maria da Rocha ${ }^{* *}$
}

\begin{abstract}
RESUMO
O modelo de desenvolvimento atual afeta a humanidade em seus valores fundamentais: meio ambiente, saúde, paz, qualidade de vida, dignidade da pessoa humana, bem-estar e justiça social. Essa degradação social e ambiental, produz desigualdades e vulnerabilidades, através de exclusões e pobreza. Em relação à mulher, esse quadro é ainda mais degradante, porque somam-se também as formas de discriminações e violências, frutos de uma sociedade historicamente patriarcal, sexista e racista. Apesar dos benefícios e melhorias para a qualidade de vida, advindos dos avanços tecnológicos e de conquistas políticas, sociais e jurídicas, a mulher ainda sofre limitações e enfrenta contradições na sociedade atual em relação aos seus direitos. Neste artigo reflete-se sobre a relação entre a saúde e os direitos humanos, sob a perspectiva dos direitos da mulher. Aborda-se a condição de vulnerabilidade, diversidade e aspectos relacionados à atenção do Estado em políticas públicas.
\end{abstract}

Palavras-chave: Educação em Saúde; Saúde da Mulher; Dignidade humana.

\begin{abstract}
The current development model affects humanity in its fundamental values: environment, health, peace, quality of life, dignity of the human person, well-being and social justice. This social and environmental degradation produces inequalities and vulnerabilities, through exclusion and poverty. In relation to women, this situation is even more degrading, because there are also forms of discrimination and violence, fruits of a historically patriarchal, sexist and racist society. Despite the benefits and improvements to the quality of life, stemming from technological advances and political, social and legal achievements, women still suffer from limitations and face contradictions in today's society in relation to their rights. This article reflects on the relationship between health and human rights from the perspective of women's rights. It addresses the condition of vulnerability, diversity and aspects related to the attention of the State in public policies.
\end{abstract}

Keywords: Health education; Women's Health; Human dignity.

\section{INTRODUÇÃO}

Uma teoria ou uma abordagem única por si só não explica a origem das situações ou condições que tornam as mulheres pessoas tão afetadas por desigualdades.
Olhar sobre o aspecto econômico, biológico, jurídico etc. é necessário, mas não é suficiente para explicar a diferença constitutiva do masculino e do feminino que está presente em todas as culturas e sociedades. Uma

\footnotetext{
*Mestranda em Saúde Pública pela Fundação Oswaldo Cruz do Rio de Janeiro - RJ. Professora da Universidade Estadual da Bahia.

${ }^{* *}$ Doutora em Saúde Pública. Pesquisadora e professora da Fundação Oswaldo Cruz do Rio de Janeiro - RJ.

*** Doutora em Saúde Pública. Pesquisadora e professora da Fundação Oswaldo Cruz do Rio de Janeiro - RJ.
} 
diferença marcante pelas desigualdades, violências e coerções de formas múltiplas e cruzadas.

Para esclarecer a situação da mulher como sujeito de direitos e a sua condição na sociedade, nesse tópico apresenta-se uma noção da abordagem de gênero, por ser esta a mais adotada atualmente pelas organizações de direitos humanos e por grande parte da literatura acadêmica.

Conforme explicam, Pena e Correia (2003, p. 37), o conceito de gênero é uma construção sociológica relativamente recente, respondendo à necessidade de diferenciar o sexo biológico de sua tradução social em papéis sociais e expectativas de comportamentos femininos e masculinos, tradução esta demarcada pelas relações de poder entre homens e mulheres vigentes na sociedade. Embora biologicamente fundamentado, o gênero é uma categoria relacional que aponta papéis e relações socialmente construídas entre homens e mulheres. São processos de aprendizado nascidos de padrões sociais estabelecidos, que são reforçados através de normas, mas também através da coerção e são modificados no tempo, refletindo as mudanças na estrutura normativa e de poder dos sistemas sociais.

O gênero refere-se aos aspectos da vida social que são vivenciados diferentemente porque homens e mulheres têm papéis diferentes que lhes são designados.

Em comentários sobre a desigualdade de gênero, Benedictis (2016, p. 27-31), anota que não é apenas o aspecto econômico o motivador das desigualdades na sociedade, pois, se assim o fosse, a mulher estaria atrelada a uma determinada classe e não sofreria discriminações. No entanto, tanto as que pertencem a um nível elitizado da sociedade, como as que pertencem a uma classe menos abastada, em certa medida, são vítimas do preconceito e discriminação. Além dos aspectos econômicos, há também os aspectos culturais, políticos e sociais que influenciam no comportamento, no modo de ser e ver de cada sociedade no tempo e espaço.

Os papéis desenvolvidos por homens e mulheres em sociedade são reflexos de um comportamento fundamentado em conceitos históricos, sociais e políticos que explicita as condutas de homens e mulheres e os seus lugares na sociedade. Por sua fragilidade, o lugar da mulher seria o espaço privado, e o do homem, por sua virilidade, o espaço público. (Idem ibidem).

Consoante explana Alembert (2004, p. 26), a história da mulher desde a antiguidade até os dias atuais, é de exclusão, invisibilidade, opressão e exploração. De modo geral, explana que o patriarcado - a relação de dominação do homem sobre a mulher - surge com a apropriação individual da riqueza material produzida por todos. Com a invenção do arado o trabalho do homem torna-se mais valorizado e o da mulher em plano inferior. Assim, o lugar principal nos clãs passa a ser dos homens que dominam tudo, inclusive as mulheres. Elas são as primeiras pessoas escravizadas, porque o homem precisava ter a certeza da legitimidade da prole para a transmissão da herança.

Para muitas sociedades, as mulheres ainda são consideradas o sexo frágil e por isso, vivem e convivem apenas no espaço doméstico. Em muitas partes do mundo, em pleno século XXI, as mulheres não possuem o direito real de mobilidade no seio da sociedade, são coagidas a negar sua natureza, a sua forma de vestir, de se comportar, ainda são concebidas como objeto de desejo, de reprodução, de domínio, sendo, portanto objetos da violência física, psicológica e simbólica. (BENEDICTIS, 2016, p. 34).

A respeito da estrutura contraditória da sociedade, que dá às mulheres algumas conquistas, mas as mantém em posições inferiores, Tohidi (2016:76), destaca as mulheres iranianas, que possuem alto índice de escolaridade superior, inclusive acima dos homens. Contudo, em muitos aspectos são inferiorizadas e privadas de liberdades mínimas em relações sociais. Segundo a autora, muitos fatores moldaram essa posição contraditória, devido principalmente ao aspecto da imposição ocidental que choca com os poderes locais.

Em setembro de 1995, a IV Conferência das Nações Unidas sobre a Mulher, realizada em Pequim, identificou as principais desigualdades sofridas pelas mulheres. Naquela época destacavam:

a. a crescente proporção de mulheres em situação de pobreza (fenômeno que passou a ser conhecido como a feminização da pobreza);

b. a desigualdade no acesso à educação e à capacitação;

c. a desigualdade no acesso aos serviços de saúde;

d. a violência contra a mulher;

e. a desigualdade quanto à participação nas estruturas econômicas, nas atividades produtivas e no acesso a recursos;

f. a desigualdade em relação à participação no poder político e nas instâncias decisórias; 
g. as deficiências na promoção e proteção dos direitos da mulher;

h. o tratamento estereotipado dos temas relativos à mulher nos meios de comunicação e a desigualdade de acesso a esses meios;

i. a desigualdade de participação nas decisões sobre o manejo dos recursos naturais e a proteção do meio ambiente. (ONU Mulheres, 2013b, p. 148-150).

Atualmente, embora alguns países apresentem avanços e mudanças para as condições das mulheres, o relatório apresentado em março de 2018 na $62^{\mathrm{a}}$ Sessão da Comissão da ONU sobre a Situação das Mulheres (CSW 62), revela que o progresso na consecução da igualdade de gênero e do empoderamento de todas as mulheres e meninas apresenta atrasos. Isso porque ainda persistem relações de poder desiguais históricas e estruturais entre mulheres e homens, nos mais variados campos, notadamente quanto a: pobreza, desigualdades e desvantagens no acesso à propriedade $\mathrm{e}$ controle sobre recursos, lacunas na igualdade de oportunidades, acesso limitado aos serviços universais de saúde e ao ensino fundamental e superior, violência de gênero, existência de leis e políticas discriminatórias, normas sociais negativas e estereótipos, bem como a desigualdade na divisão de tarefas de cuidados o trabalho doméstico não remunerado. (ONU Mulheres, 2018, s.n.p.).

Essa persistência de relações de poder desiguais históricas e estruturais possui uma lógica de articulação causal com explicações variadas. Em pesquisa sobre as mudanças estruturais e estratificação no Brasil, período de 1980 a 2000, Hasenbalg e Silva (2003, p. 37 ), estudaram como as desigualdades sociais continuam e são transmitidas ao longo da vida.

Destacam que há uma articulação entre as diversas dimensões de desigualdades no decurso das etapas do ciclo de vida individual, através das quais ocorre a transmissão intergeracional desde sua origem no contexto familiar de nascimento até a situação atual das famílias em que uma nova geração é produzida. São determinadas pela situação destes indivíduos nas etapas anteriores da vida, em relação a aspectos como: situação social das famílias, saúde, sobrevivência e acesso à pré-escola e a escolarização formal; aquisição do status social próprio mediante acesso ao mercado de trabalho e escolha marital. (Idem, p. 38-40).
Os resultados apurados pelos pesquisadores revelam um quadro de grandes desigualdades e dificuldades socioeconômicas para as mulheres brasileiras, principalmente para as adolescentes negras e pardas das classes sociais mais baixas, baixa escolaridade, chefias de família monoparental e gravidez na adolescência. As brasileiras desse perfil contam com sérias desvantagens na apropriação e acumulação dos capitais social, cultural e econômico, configurando assim contextos mais desfavoráveis para a socialização de novas gerações. (Idem, p. 55-81).

Entretanto, a distribuição de recursos e oportunidades para essas mulheres também possuem determinantes exógenos ao sistema de transmissão, que implicam em possibilidade de modificação corretiva dos níveis de desigualdade até certos limites. São modificações resultantes de políticas públicas, que podem ter impacto positivo ou negativo sobre o quadro de desigualdades, e assim alterar as oportunidades oferecidas nas etapas subsequentes do ciclo de vida. Como exemplos dessas modificações os autores citam o acesso à escolarização formal e ao mercado de trabalho. (Idem, p. 38).

A partir dessas exposições, este estudo é uma reflexão sobre as condições de vida e saúde das mulheres e seus direitos, a partir dos princípios e diretrizes do Plano Nacional de Políticas para Mulheres (PNPM) e da Política Nacional de Atenção Integral à Saúde da Mulher (PNAISM), considerando-se a abordagem da promoção da saúde. Além desses documentos, buscou-se também a fundamentação em publicações de autores e pesquisadores da temática. $\mathrm{O}$ trabalho foi realizado no período de 2017-2018 como análise documental simples de identificação, leitura e interpretação das fontes por raciocínio crítico.

Baseando-se da Carta de Ottawa (1986), a Organização Mundial da Saúde (OMS), considera que a promoção da saúde é um novo paradigma para uma nova saúde pública, em resposta às necessidades da saúde, para além das concepções e modelos biomédicos tradicionais. Sua inserção no campo da saúde trouxe revitalização ao definir as condições fundamentais para a saúde: paz, moradia, educação, alimentação, ecossistema estável, recursos sustentáveis, justiça social e equidade. (BRASIL, 2002a:5-6). Desse modo, a importância da abordagem da promoção da saúde para a mulher está no princípio essencial de 
empoderamento, para o desenvolvimento sustentável das capacidades de vida e saúde.

\section{PERSISTENTES DESIGUALDADES DE GÊNERO}

O relatório de acompanhamento da Agenda 2030 da ONU para o Desenvolvimento Sustentável, lançado em março 2018, indica que ainda é muito lento o progresso das mulheres e meninas em relação à desigualdade de gênero. Entre os principais dados apontados, em nível mundial, estão os seguintes:

a. Apesar dos avanços em matrícula de meninas no ensino fundamental, 15 milhões de meninas em idade escolar nunca terão o oportunidade de aprender a ler e escrever na escola primária, em comparação com 10 milhões de meninos;

b. A violência contra mulheres e meninas continua sendo uma pandemia global: uma em cada três mulheres e meninas experimenta violência física ou sexual ao longo de sua vida;

c. As mulheres ocupam apenas $23,7 \%$ dos assentos parlamentares, um aumento de 10 pontos percentuais em relação ao ano 2000 , embora ainda muito abaixo de paridade;

d. Existem 122 mulheres, com idade entre 25 a 34anos, que vivem em condições de extrema pobreza, para cada 100 homens do mesmo grupo de idade;

e. As mulheres representam $28,8 \%$ das pessoas que trabalham com pesquisa e inovação científica. Em apenas um de cada cinco países há paridade de gênero nesse âmbito;

f. As mulheres têm até $11 \%$ mais chances de padecer por insegurança alimentar do que os homens;

g. Entre 2010 e 2015, o mundo perdeu 3,3 milhões de hectares de área florestal. Mulheres pobres das áreas rurais que dependem dos recursos de uso comum são especialmente afetadas quando estes diminuem;

h. As mulheres dedicam 2,6 vezes mais tempo em trabalho doméstico e cuidados não remunerados do que os homens;

i. A mudança climática tem impacto desproporcional em mulheres e meninas, já que é 14 vezes mais provável que morra durante um desastre do que os homens; j. A diferença salarial entre os sexos está em 23\%; a taxa de atividade das mulheres é $63 \%$, enquanto que a dos homens é 94\%. (ONU MUJERES, 2018:20-21). (tradução livre).

Segundo o balanço feito pela Comissão desse relatório, é alarmante ver que muitas das conquistas duramente alcançadas em termos de igualdade de gênero estão ameaçadas. Apontam como principais ameaças às conquistas da igualdade: a mudança climática e a degradação ambiental; a desaceleração da economia, a recessão e a austeridade fiscal. A mudança para uma política de exclusão, baseada no medo está aprofundando divisões sociais, fomentando conflitos e instabilidades, e renovando a resistência aos direitos das mulheres. (Idem, p.14). (tradução livre).

No Brasil, os dados do Instituto Brasileiro de Geografia e Estatística (IBGE), demonstram que, além das desigualdades de gênero, as desigualdades raciais e geográficas que afetam as mulheres se colocam como desafios a serem enfrentados:

o tempo dedicado aos cuidados de pessoas e/ou afazeres domésticos em $\mathrm{h} /$ semana: considerando-se a população em geral é de $18,1 \mathrm{~h}$ para mulheres e $10,5 \mathrm{~h}$ para os homens. Em relação à etnia para as mulheres brancas é de 17,7h; e para as negras é de 18,6h;

o rendimento habitual médio mensal é de $\mathrm{R} \$ 1.764,00$ para mulheres, e $\mathrm{R} \$ 2.306,00$ para os homens. Segundo o IBGE as mulheres seguem recebendo cerca de $25 \%$ a menos do que os homens;

o nível educacional superior completo em relação à população a partir de 25 anos de idade: na população branca $23,5 \%$ das mulheres e $20,7 \%$; na população negra as mulheres representam 10,4\% e os homens $7,0 \%$;

nos espaços de decisão: as mulheres são 10,5\% da representação política na câmara dos deputados; nos cargos gerenciais as mulheres ocupam apenas $39,1 \%$; e,

a taxa de fecundidade para mulheres de 15 a 19 anos de idade representa $85,1 \%$ na região Norte; $64,9 \%$ Nordeste; $55,6 \%$ Centro-oeste; $45,4 \%$ Sudeste e 45,6\% Sul. (INFORME IBGE, 2018:n.38).

No que se refere aos direitos sexuais e reprodutivos, as mulheres têm mais vias de acesso aos serviços e à assistência em saúde do que os homens, mas perdura a visão reprodutiva para elas e da sexualidade para eles. Apesar dos esforços engendrados através da 
PNAISM, a sexualidade recebe pouca articulação com outros aspectos das mulheres que estão além do reprodutivo, tais como: violência, estereótipos, identidade sexual e aborto. (ONU BRASIL, 2018:9).

Os dados evidenciam que, embora tenham conseguido grandes conquistas em mudanças sociais e econômicas, as desigualdades de gênero ainda persistem no Brasil, especialmente para as mulheres negras. Pode-se inferir que são desigualdades estruturais históricas, caracterizando-se como desvantagens acumuladas em gerações. As mazelas do sexismo, do racismo e da escravidão ainda estão presentes na sociedade brasileira, afetam mais as mulheres pobres.

\section{A IMPORTÂNCIA DA IGUALDADE DE GÊNERO}

A partir das décadas de 1970 a 1980, a ONU, lançou vários relatórios do Programa das Nações Unidas para o Desenvolvimento Humano (PNUD), com resultados de pesquisas sobre as condições das mulheres em vários países. Nesses relatórios sugeria que os governos tomassem providências para erradicar explorações e violências, e para atenção especial à desigualdade de gênero.

Em 1979, a ONU realizou a Convenção sobre a Eliminação de Todas as Formas de Discriminação contra as Mulheres (Convenção da Mulher ou CEDAW). Dessa convenção surgiu uma reafirmação da declaração da igualdade presente na Declaração Universal dos Direitos Humanos, dando início a um importante período para a luta contra a discriminação e desigualdade de gênero em nível mundial, ao considerar que:

[...] a Declaração Universal dos Direitos Humanos reafirma o princípio da não-discriminação e proclama que todos os seres humanos nascem livres e iguais em dignidade e direitos e que toda pessoa pode invocar todos os direitos e liberdades proclamados nessa Declaração, sem distinção alguma, inclusive de sexo. (BRASIL, 2002, s.n.p.).

Nessa declaração a explicação em prol da igualdade de gênero refere-se que a discriminação contra a mulher viola os princípios da igualdade de direitos e do respeito da dignidade humana; constitui-se em um obstáculo ao aumento do bem-estar da sociedade e da família e dificulta o pleno desenvolvimento das potencialidades da mulher, pois a participação máxima da mulher, em igualdade de condições com o homem, em todos os campos, é indispensável para o desenvolvimento pleno e completo de um país, o bem-estar do mundo e a causa da paz. (BRASIL, 2002b, s.n.p.).

No relatório de acompanhamento dos Objetivos do Desenvolvimento Sustentável da Agenda 2030, o atual Secretário Geral das Nações Unidas, António Guterres, descreve a importância da igualdade de gênero através do seguinte alerta:

A criação de sociedades inclusivas e pacíficas estará fora do nosso alcance até que as mulheres e meninas estejam a salvo de todas as formas de violência, e possam influenciar nas decisões que afetam suas vidas. A igualdade de gênero é um objetivo por direito próprio, e um poderoso motor para defender a promessa principal da Agenda 2030: não deixar ninguém para trás. (ONU MUJERES, 2018, p. 2). (tradução livre). (grifos nossos).

O supracitado relatório apresenta o papel e a importância das mulheres como efeitos catalizadores para atingir os objetivos da agenda, e também a repercussão dos efeitos da violência contra elas. Em comentário geral sobre a importância da igualdade de gênero expõe sobre os seguintes aspectos, especialmente no que se refere à saúde e bem estar:

a. mulheres e meninas representam metade da população em todo o mundo, portanto, representam metade do potencial humano mundial. Quando a vida delas melhora, os benefícios repercutem em toda a sociedade;

b. o acesso de mulheres a trabalho decente e renda regular, não só contribui para a redução da pobreza, mas também ajuda a alcançar melhores resultados na educação, saúde e nutrição das mulheres, crianças e daqueles que dependem delas;

c. da mesma forma, a eliminação de todas as formas de violência contra mulheres e meninas não é apenas um componente fundamental por si só, mas também é crucial para garantir uma vida saudável e bem-estar de pessoas de todas as idades;

d. as consequências para a saúde por violência contra mulheres e meninas são estendidas aos filhos, já que filhas e filhos testemunham abusos e traumas prolongados sofridos por elas, que afetam seu desenvolvimento físico, emocional e social. 
Portanto, a eliminação de restrições específicas de gênero, bem como outras formas de discriminação com as quais se cruzam, é transcendental. (ONU MUJERES, 2018, 73). (tradução livre).

Destaca-se também a Declaração sobre o Direito ao Desenvolvimento, instituída pela ONU em 1986. Nos dispositivos $1^{\circ}$ e $8^{\circ}$ estabelece que o direito ao desenvolvimento é um direito humano inalienável, do qual toda pessoa e todos os povos estão habilitados a participar do desenvolvimento econômico, social, cultural e político, para contribuir e dele desfrutar. Por este motivo os Estados devem tomar todas as medidas necessárias e efetivas para assegurar que as mulheres tenham um papel ativo no processo de desenvolvimento. (ONU,1986, s.n.p.).

Compreende-se que a defesa do direito à igualdade de gênero, implica em tratamento e oportunidades iguais para homens e mulheres. Para as mulheres essa igualdade implica em liberdade de suas capacidades para o desenvolvimento. $\mathrm{O}$ respeito aos direitos das mulheres, através de políticas sociais públicas e privadas, é fundamental para haver desenvolvimento humano sustentável.

\section{ESCORÇO HISTÓRICO SOBRE A LUTA PELOS DIREITOS DA MULHER}

A luta da mulher para conquistar e garantir seus direitos estabelece-se como uma relação de gêneros, por ser uma relação construída social, cultural e historicamente sob a forma de dominação do sexo masculino sobre o feminino. Assim, as diferenças para submissão e inferiorização da mulher são construções, não sendo aqui tomadas como aspectos relativos à condição biológica.

\section{A LUTA PELOS DIREITOS DA MULHER NA EUROPA E NO MUNDO}

Sob uma perspectiva histórica mais formalizada e mais divulgada como marco temporal, os direitos e a relação de gênero como forma de reivindicação iniciou-se na França, a partir da Revolução de 1789, como forma de chamar a atenção sobre uma revolução que não havia alcançado as mulheres francesas plenamente. Consoante explica Pinsky (2003, p. 269), durante a Revolução francesa:
[...] numerosas francesas questionaram o Estado e a economia, exigiram direitos e organizaram grupos e instituições para representar seus interesses. [...]. Entretanto, o desenrolar do movimento revolucionário desaponta as mulheres, [...] ao lhes proporcionar ganhos limitados [...] e proibir sua atuação política em 1793. A maior parte dos homens que apoiavam a Revolução não achava que liberdade, igualdade $\mathrm{e}$ fraternidade estendiam-se às mulheres, sendo favoráveis a sua volta à vida doméstica, para não subverterem a "natureza", exigindo participação direta nos assuntos do Estado.

Desse modo, a declaração criada para espalhar-se pelos povos e influenciar os sistemas políticos e jurídicos, consoante desejavam os franceses: "Queremos fazer uma declaração para todos os homens, para todos os tempos e para todos os países", não favorecia as mulheres. Os princípios consagrados eram direitos masculinos, os cidadãos ativos eram os homens. (BRANDÃO, 2001, p. 98). As mulheres mais uma vez ficaram relegadas ao âmbito doméstico tido como naturalmente feminino, sem acesso ao âmbito público tido como naturalmente masculino.

Todavia, inspiradas pela Declaração dos Direitos do Homem e do Cidadão de 1789, algumas mulheres propuseram a aplicação dessa declaração também às mulheres. Lideradas pela francesa Olympe de Gouges (pseudônimo de Marie Gouze), em 1791publicaram a Declaração da Mulher e da Cidadã que, dentre as assertivas dizia: "A mulher nasce livre e seus direitos são os mesmos dos homens". (MACHADO, 2003, p. 122).

A declaração proposta por Olympe serve "ao mesmo tempo como apelo às mulheres para que elas se posicionassem responsavelmente frente ao que (lhes) acontecia". (ASSMANN, 2007, s.n.p.).

A Declaração da Mulher e da Cidadã contém reivindicações de direitos relacionados: a liberdade, a propriedade, a segurança, e a resistência à opressão. Faz uma convocação às mulheres para que tomem seus destinos em suas mãos e lutem por seus direitos: "Mulher, acorda! A força da razão faz-se ouvir em todo o universo: reconhece teus direitos. (Idem ibdem).

Outro fato histórico que marcou de forma trágica a história de luta das mulheres por seus direitos, aconteceu em Nova York no dia 8 de março de 1857: operárias de uma fábrica de tecidos entraram em greve para reivindicar redução da carga horária diária de trabalho, equiparação de salários com os homens e tratamento 
digno dentro do ambiente de trabalho. As operárias teriam sido trancadas na fábrica e aproximadamente 130 morreram queimadas, após um incêndio. O Dia Internacional da Mulher foi instituído em memória daquelas mulheres. (AMARANTE, 2008, s.n.p.).

Em 1946 a ONU instituiu a Comissão sobre o Status da Mulher (CSW), com o objetivo de estudar, analisar e criar recomendações que oferecessem subsídios à formulação de políticas, para o desenvolvimento das mulheres enquanto seres humanos. No período de 1949 a 1962, a CSW estudou a condição das mulheres no mundo, o que culminou na elaboração de vários documentos sobre os direitos da mulher pela ONU: Convenção dos Direitos Políticos das Mulheres (1952), Convenção sobre a Nacionalidade das Mulheres Casadas (1957), Convenção sobre o Casamento por Consenso, Idade Mínima para Casamento e Registro de Casamentos (1962). Em 1967, elaborou a Declaração sobre a Eliminação da Discriminação contra a Mulher, que se constituiu em um instrumento legal de padrões internacionais, propondo direitos iguais para homens e mulheres, contudo não chegou a ser efetivada como tratado, pois não estabeleceu obrigações aos Estados signatários. Essa Declaração considerava "a importância da contribuição da mulher à vida social, política, econômica e cultural, assim como sua função na família e especialmente na educação dos filhos". (SOUZA, 2009, p. 348-49).

A partir dos relatórios do PNUD (1970 a 1980), novo impulso foi dado em apoio aos direitos das mulheres em vários países. Em 1972 a ONU, através da Resolução 3010 (XXVII), proclamou 1975 como o Ano Internacional da Mulher. E através da Resolução 3520 (XXX), proclamou o período 19761985 Decênio da ONU para a Mulher, com os temas Igualdade, Desenvolvimento e Paz.

Esses acontecimentos impulsionaram a ONU a aprovar a Convenção sobre a Eliminação de todas as Formas de Discriminação contra a Mulher (CEDAW), aprovada em 18 de dezembro de 1979 por meio da resolução n. A-34-180, que entrou em vigor em 3 de setembro de1981, após atingir o número mínimo de 20 ratificações. Dentre as Convenções da ONU, a CEDAW foi a que mais recebeu reservas por parte dos países que a ratificaram. (MELO, 1999, p. 87). O Brasil foi um dos países que apresentou vetos à Convenção e a adotou tardiamente.
Na Conferência de Viena (1993), o movimento de mulheres levou a bandeira de luta: "os direitos da mulher também são direitos humanos". E pela primeira vez foram reconhecidos em uma assembleia mundial, constando na Declaração e Programa de Ação de Viena (item 18): "Os direitos humanos das mulheres e das meninas são inalienáveis e constituem parte integral e indivisível dos direitos humanos universais." (ONU MULHERES, 2013a, s.n.p.).

Em 1995 a ONU realizou em Pequim (China), a IV Conferência das Nações Unidas sobre a Mulher, intitulada "Ação para a Igualdade, o Desenvolvimento e a Paz". É considerada a mais importante das CSW, pelos avanços conceituais e programáticos que propiciou, e pela influência que continua a ter na promoção da situação da mulher. Essa Conferência partiu de uma avaliação dos avanços obtidos desde as conferências anteriores (Nairobi, 1985; Copenhague, 1980; e México, 1975) e de uma análise dos obstáculos a superar para que as mulheres possam exercer plenamente seus direitos, e alcançam seu desenvolvimento integral como pessoas. (ONU Mulheres, 2013b, p.148).

A Plataforma de Ação de Pequim consagrou três inovações dotadas de grande potencial transformador na luta pela promoção da situação e dos direitos da mulher:

a. o conceito de gênero permite compreender as relações entre homens e mulheres como produto de padrões determinados social e culturalmente, portanto passíveis de modificação para a superação dos padrões de desigualdade;

b. o empoderamento da mulher realça a mulher para adquirir controle sobre o seu desenvolvimento, devendo o governo e a sociedade criar as condições e apoiá-la nesse processo;

c. a noção de transversalidade busca assegurar que a perspectiva de gênero passe efetivamente a integrar as políticas públicas em todas as esferas de atuação governamental.

A essas inovações conceituais veio juntar-se a ênfase no tratamento da situação da mulher sob a perspectiva de direitos, o que implica reconhecer que a desigualdade entre homens e mulheres é uma questão de direitos humanos, e não apenas uma situação decorrente de problemas econômicos e sociais a serem superados. (ONU Mulheres, 2013b, p. 149).

Outra conquista histórica para as mulheres veio através da Convenção Interamericana para Prevenir, 
Punir e Erradicar a Violência Contra a Mulher realizada no ano de 1994, em Belém do Pará (Brasil). Entre os pontos declarados destacam-se que: a violência contra a mulher constitui uma violação dos direitos humanos e das liberdades fundamentais; é uma ofensa à dignidade humana; transcende todos os setores da sociedade e afeta negativamente suas próprias bases; a eliminação da violência contra a mulher é condição indispensável para seu desenvolvimento individual e social. (ONU Mulheres, 2013c, s.n.p.).

Atualmente, em todos os países as mulheres continuam em mobilizações por suas conquistas. Mas ainda enfrentam grandes entraves na luta por seus direitos, com destaque para o aumento das violências:

Os avanços normativos, desde a criação da Convenção sobre a Eliminação de todas as Formas de Discriminação Contra as Mulheres (CEDAW na sua sigla em inglês) em 1979, demonstraram ser mais formais que efetivos. Adicionalmente, a coerção física, central na estruturação desigual da relação entre os sexos, paira como ameaça permanente. A maior presença das mulheres no espaço público vem acompanhada por índices alarmantes de violência de gênero. E, apesar de, na virada do século, os direitos sexuais e reprodutivos terem sido reconhecidos como direitos humanos, a ofensiva conservadora contra a ideologia de gênero vem ganhando adesão crescente e corroendo conquistas. (COSTA, 2016:5). (grifos nossos).

A luta pelos direitos, sob a perspectiva da relação de gêneros, implicou em observar que as prerrogativas humanas e universais foram cerceadas, mitigadas e até mesmo negadas para as mulheres por séculos em vários países. E até hoje assim acontece em alguns países que mantêm matrizes culturais baseadas no patriarcado e no machismo. Ainda hoje assistimos pequenos avanços ocorrerem em alguns países do oriente médio, como a Arábia Saudita, que nesse ano de 2018 permitiu que as mulheres frequentem locais de entretenimento como ginásios de esportes e cinemas, e possam dirigir veículos.

Logo, foi de forma indireta que a Revolução francesa, o ataque incendiário à fábrica têxtil e outros episódios de lutas e sacrifícios, favoreceram as posteriores lutas das mulheres por seus direitos, em todo o mundo. Nota-se que a conquista de direitos pelas mulheres aconteceu graças ao envolvimento e engajamento das próprias mulheres em trajetórias de denúncias, resistências e quebras de paradigmas. De atos de coragem de mulheres que se dedicaram (e se dedicam) a lutar contra a desigualdade e a fortalecer a democracia e a cidadania em prol das mulheres.

\section{A LUTA PELOS DIREITOS DA MULHER NO BRASIL}

No Brasil, a história de luta das mulheres por seus direitos pode ser pontuada como marco temporal entre o fim do século XVIII e início do XIX, com a luta por direitos iguais, reivindicações por direitos democráticos, liberdade sexual e também os de caráter sindical, ambos buscando a igualdade entre os gêneros. Conforme explanam Soares e Andrade (2016, s.n.p.):

No Brasil, o movimento tomou forma entre o fim do século 18 e início do 19, quando as mulheres brasileiras começaram a se organizar e conquistar espaço na área da educação e do trabalho. Três momentos de maiores relevâncias. O primeiro; que foi motivado pelas reivindicações pelos direitos democráticos, tendo como exemplo o direito ao voto, divórcio, trabalho, o segundo; ocorrido na década de 60 , que foi marcado pela luta à liberdade sexual, e o terceiro, que começou a se constituir no fim dos anos 70, com uma luta de caráter sindical. Em ambos os períodos, clamava-se o cumprimento do texto constitucional, não apenas na prática formal, mas na efetiva.

O movimento de mulheres no Brasil passa a ser considerado como um ato político de relevância, em meados da década de 1970, enquanto o país ainda vivia sob um regime militar. Lutavam contra o regime ditatorial em exercício no país, com suas manifestações amplia os conceitos outrora aplicados à democracia e a igualdade, pois denuncia as discriminações sofridas pelas mulheres na esfera política e social.

No período pós ditadura militar, marcado pela presença do povo através de movimentos sociais em defesa da democracia e luta para o reconhecimento de direitos pela implantação do Estado Democrático de Direito no Brasil, as mulheres surgem como uma nova forma de organização. Em 1985, diante do contexto do movimento denominado de Diretas Já, surge o Conselho Nacional dos Direitos da Mulher, que visava desenvolver políticas públicas para melhoria na condição da mulher, propondo novas leis e programas, além de aconselhar a presidência e os ministérios para 
que houvesse o desenvolvimento de projetos mais específicos. Conseguiu-se a aprovação da Carta das Mulheres Brasileiras aos Constituintes, que apresentava as propostas das mulheres para a criação de uma ordenação normativa que evidenciasse a igualdade entre os seres, independentemente do gênero, sendo dever do Estado a garantia da aplicabilidade de tal. Algumas propostas das mulheres iam além do papel que o Estado exercera até então, expandindo o conceito de direitos humanos (PITANGUY, 2008, s.n.p.).

Por essa atuação, o Conselho Nacional dos Direitos da Mulher ficou conhecido como o lobby do batom, e obteve importantes avanços nas leis que garantem a igualdade de direitos e obrigações entre homens e mulheres na nova Constituição promulgada em 1988.

Em relação à CEDAW, o Congresso Nacional Brasileiro pelo Decreto Legislativo n. 26, de 22 de junho de 1994, revogou o citado Decreto Legislativo $\mathrm{n}^{\circ}$ 93, aprovando sem ressalvas a Convenção da Mulher. (BRASIL, 2002b, s.n.p.).

\section{DIREITOS HUMANOS, SAÚDE E DIREITOS DA MULHER}

A luta das mulheres em busca de melhores condições de sobrevivência, vida e existência, acontece pela reivindicação de direitos em todas as áreas, mas sobretudo pelo reconhecimento da igualdade de direitos entre homens e mulheres.

Pode-se considerar que esse reconhecimento à igualdade teve como importante ponto de aproximação a Declaração Universal de Direitos Humanos, proclamada pela Resolução n. 217 A (III) da Assembleia Geral das Nações Unidas em 1948: a "dignidade inerente a todos os membros da família humana e de seus direitos iguais e inalienáveis é o fundamento da liberdade, da justiça e da paz no mundo." (ONU, 1948).

O princípio da igualdade está atrelado ao princípio da dignidade, conforme estabelece a mesma Declaração: "Art. $1^{\circ}$ - Todos as pessoas nascem livres e iguais em dignidade e direitos. São dotadas de razão e consciência e devem agir em relação umas às outras com espírito de fraternidade. (Idem ibdem).

Todavia, foi a II Conferência Mundial de Direitos Humanos (Viena 1993), que reconhece ser responsabilidade dos Estados membros "proteger e promover os direitos humanos e liberdades fundamentais de todas as pessoas sem distinção de raça, sexo, idioma ou religião".

Além de reafirmar a igualdade abstrata para toda a humanidade, a Conferência de Viena foi histórica ao reconhecer de forma específica os direitos das mulheres e das meninas como parte integrante e indivisível dos direitos humanos universais, e explicitar que a violência contra as mulheres constitui violação dos direitos humanos: "Os direitos humanos das mulheres e das meninas são inalienáveis e constituem parte integral e indivisível dos direitos humanos universais." A plena participação das mulheres, são objetivos prioritários da comunidade internacional. A violência e todas as formas de abuso e exploração, preconceito cultural e o tráfico internacional de pessoas, são incompatíveis com a dignidade e valor da pessoa humana e devem ser eliminadas. A Conferência Mundial sobre Direitos Humanos insta a todos a intensificarem seus esforços em prol da proteção e promoção dos direitos humanos da mulher e da menina. (ONU MULHERES, 2013a, s.n.p.).

Em seu art. 25, I, a Declaração Universal de Direitos Humanos defende que o direito à saúde constitui-se em um dos direitos humanos: "Toda a pessoa tem direito a um padrão de vida capaz de assegurar a si e a sua família saúde e bem estar, inclusive alimentação, vestuário, habitação, cuidados médicos e os serviços sociais indispensáveis" (ONU, 1948).

Nesse sentido, em relação aos direitos da mulher, a CEDAW destacou que "em situações de pobreza, a mulher tem um acesso mínimo à alimentação, à saúde, à educação, à capacitação e às oportunidades de emprego, assim como à satisfação de outras necessidades. (BRASIL, 2002b, s.n.p.).

Com base nesse fato de vulnerabilidades, para combater a discriminação da mulher em aspectos relacionados à saúde, a CEDAW declara:

\section{Artigo $11^{\circ}$}

Os Estados-Partes adotarão todas as medidas apropriadas para eliminar a discriminação contra a mulher na esfera do emprego a fim de assegurar, em condições de igualdade entre homens e mulheres, os mesmos direitos, em particular. (BRASIL, 2002b, s.n.p.).

Na Declaração de Pequim (1995), a ONU reafirmou esses direitos, e especificamente enfatizou:

12. O empoderamento e o avanço das mulheres, lhes garantindo possibilidade de construírem suas vidas de acordo com suas próprias aspirações; 


\section{$[\ldots]$}

16. A erradicação da pobreza requer a participação da mulher no processo de desenvolvimento econômico e social, oportunidades iguais e a plena participação, em condições de igualdade. (ONU Mulheres, 2013b, p. 151-52).

A Carta da CEDAW (1979) e a Declaração de Viena (1993), representam os amparos supralegais dos direitos da mulher. Implicam em obrigações legais aos Estados-membros da ONU, por serem responsáveis para garantir os direitos da mulher sem discriminações. Por isso essas cartas são os instrumentos mais importantes para nortear a regulamentação dos direitos da mulher nos países signatários, contribuem efetiva e significativamente com as comissões ao elaborarem e implementarem políticas públicas para mulheres.

A ampliação do conceito de saúde, para além dos critérios estritamente biológicos intrínsecos ao corpo humano, favorece de modo a interferir positivamente na concepção de saúde como direito, portanto intimamente ligado à dignidade da pessoa humana, a saúde como direitos humanos.

O direito à saúde é um dos direitos humanos, necessário para o respeito à dignidade da pessoa humana e exercício da cidadania. Por isso, ele é indispensável à preservação e promoção da dignidade em três aspectos de abrangência: do individual, do outro e do coletivo. É o que consta na Lei Orgânica da Saúde (Lei n.8080/90), ao instituir em seu art. $3^{\circ}$, parágrafo único, que todas as ações que se destinam a garantir às pessoas e à coletividade condições de bem-estar físico, mental e social, estão relacionadas à saúde.

Assim, com base nos direitos humanos, sua efetivação como direito fundamental na Constituição, e pela amplidão de fatores abraçados pelo conceito de saúde dado pela ONU, entende-se que os direitos da mulher fundamentam-se na dignidade da pessoa humana, que a torna livre e igual em dignidade e direitos como membro da família humana.

\section{OS DIREITOS DA MULHER NO ORDENAMENTO JURÍDICO BRASILEIRO}

A Constituição Brasileira de 1988 instituiu como um dos princípios fundamentais e objetivos da República, a não discriminação. Por meio do art. $3^{\circ}$ declara que são objetivos fundamentais da República
Federativa do Brasil construir uma sociedade livre, justa e solidária e promover o bem de todos, sem preconceitos de origem, raça, sexo, cor, idade e quaisquer outras formas de discriminação. (BRASIL, 2016, p. 11).

Além disso, a Carta Magna determinou a igualdade jurídica ao decretar em seu art. $5^{\circ}$, que todos são iguais perante a lei, sem distinção de qualquer natureza, homens e mulheres são iguais em direitos e obrigações. (BRASIL, 2016, p. 11).

O referido artigo traz em seu texto os direitos fundamentais, eliminando quaisquer tipos de discriminação ao gozo desses direitos, e de forma específica determina o princípio da isonomia, retirando a desigualdade nas relações de gênero, que pesava sobre a sociedade brasileira, composta em sua maioria por mulheres. A partir de então o Estado compromete-se a tutelar o direito da mulher à igualdade de direitos.

Ainda em relação à igualdade entre gêneros, a Constituição expressamente determina a igualdade no que diz respeito às relações da vida conjugal: "Art. 226. (Omissis) $\S 5^{\circ}$ Os direitos e deveres referentes à sociedade conjugal são exercidos igualmente pelo homem e pela mulher." (Idem, p.81).

Além da igualdade jurídica nos aspectos civis, como sujeito de direitos a mulher obteve proteção também em outras áreas do Direito. Sobre esse assunto, Gomes (2003:59-60), comenta que o Diploma Legal reconheceu e positivou "demandas contra a não discriminação da mão-de-obra feminina, a proteção à gestante e à empregada-mãe".

Como outros exemplos de proteção ao trabalho da mulher, cita-se a Lei n.9.029/95, que proíbe o uso de atestados de gravidez e esterilização, e de outras exigências discriminatórias para admissão ou de permanência em vínculo de trabalho. (VADE MECUM, 2013, p. 750).

E no sentido de retirar os entraves legais à emancipação da mulher, cita-se a lei: Lei n.10.406/ 2002, o novo Código Civil Brasileiro que retirou os entraves à independência e capacidade da vida civil da mulher. As leis que alteraram o Código Penal Brasileiro: Lei n. 10.886/ 2004 que tratou de proteger também a mulher no âmbito familiar, ao instituir lei contra a violência doméstica; Lei n.11.106/2005 e Lei n.12.015/2009, que dão tratamento diferenciado à proteção do corpo e vida da mulher contra abusos e violência sexual. (Idem, p.249; 594; 609). 
Sob o aspecto da proteção, atualmente o maior símbolo é a Lei n.11.340/06, a Lei Maria da Penha, que dispõe especificamente sobre a violência doméstica e familiar contra a mulher, tanto para a repressão quanto para a prevenção e erradicação da violência de gênero. (Idem, p.1789).

Recentemente a Lei n. 13.104/2015, de modo específico tipifica o feminicídio como homicídio qualificado e inclui no rol dos crimes hediondos. (BRASIL, 2015).

Todas essas leis foram criadas nos moldes de proteção e garantias preconizadas pela Constituição Federal de 1988. Desse modo, a Constituição de 1988 é um marco na luta pela igualdade de direitos entre os sexos, bem como na positivação de uma gama de direitos no que tange à situação jurídica da mulher brasileira.

\section{DIREITO À IGUALDADE E DIREITO À DIFERENÇA DA MULHER}

O princípio da igualdade (ou da isonomia), amplamente adotado pela Constituição Federal de 1988, segundo explicação de Diniz (1998:756), traduz a ideia de igual condições de direito à vida, à liberdade e à propriedade para que alguém possa alcançar posição segundo a sua capacidade; o que não basta para aqueles que são de uma forma ou de outra desfavorecidos, quer em razão de sexo, idade, cor, estado civil, convicção política ou religiosa, classe econômica ou social.

Observa-se que o termo é tomado em duas acepções, a primeira evoca um nivelamento de todos perante os poderes estatais como sujeitos de direitos pela característica, pela essência que todos possuem: a dignidade humana. A segunda evoca a necessidade de um desnivelamento como recurso para que a primeira acepção seja satisfeita, diante de condições de especialidades fáticas e/ou axiológicas, como é o caso da mulher, que enfrenta desigualdades sociais e de valores.

É justamente sobre essa segunda acepção que Souza Santos (2003:56), trata como o direito à diferença, ao considerar que: "Temos o direito a ser iguais quando a nossa diferença nos inferioriza; e temos o direito a ser diferentes quando a nossa igualdade nos descaracteriza."
Tal consideração fundamenta-se na necessidade de respeitar a diversidade existente em uma sociedade. Conforme explica Kamimura et al. (2017, p. 72):

Temos o direito de ser tratados igualmente, sem discriminação alguma. Mas também temos o direito a ser tratados diferentemente de acordo com nossas diferenças. $\mathrm{O}$ direito à igualdade, portanto, deve contemplar o respeito à diversidade. É preciso que a igualdade reconheça as diferenças e é fundamental que uma diferença não produza, fomente ou reproduza desigualdades.

Portanto, além da igualdade como efeito geral para todos reconhecida e garantida constitucionalmente como fundamento da nossa República, o poder legislativo brasileiro baseia-se nessa acepção de direito à diferença para atingir o direito à igualdade. Para reconhecer e estabelecer em leis constitucionais e infraconstitucionais um discrímen, apoiado no princípio da especialidade, decorrente do princípio da igualdade. O princípio da especialidade, desdobrando-se do princípio da isonomia, propugna o tratamento desigual do que é desigual, fazendo-se as diferenciações fáticas e axiológicas. (DINIZ, 2010, p. 468).

A explicação de Steinmetz (2001, p. 177), sobre o princípio da igualdade poder envolver uma discriminação positiva, passa pela compreensão de que os fatores usados como discriminação não rompem com a ordem isonômica, porque não são arbitrários nem absurdos. As discriminações entre sujeitos de direito são possíveis, desde que fundamentadas na razoabilidade e na proporcionalidade. O que se protege são as finalidades envolvidas por essa discriminação positiva.

É por meio desse princípio que a mulher tem o direito à igualdade para não ser inferiorizada, e também o direito à diferença para não ser excluída. Ambos precisam ser reconhecidos, respeitados e concretizados legalmente e socialmente.

Isso porque a igualdade de direitos entre os sexos, nos moldes da sociedade como a conhecemos, tem requerido que a igualdade jurídica seja a condição primeira da igualdade de fato. Para melhor compreensão, na citação de Steinmetz (2001, p. 178), significa que:

Até admitindo que uma igualdade real preexiste em virtude de qualquer causa, ela não subsistiria sem a garantia do direito. Não se forma uma sociedade de iguais se os seus membros não têm, antes de qualquer coisa, o direito de serem iguais. Sem a garantia do direito, a igualdade ficaria privada de efeito (...) 
mas a igualdade jurídica é também a condição para que a igualdade real seja real.

Em Piovesan (1992, p. 39), encontra-se explicada tal relação de igualdade jurídica sob a égide da proteção, como norma de proteção em abstrato (geral) e a norma específica, para legitimar uma diferença perante a lei:

sistema especial de proteção realça o processo de especificação do sujeito de direito, no qual o sujeito passa a ser visto em sua especificidade e concreticidade (ex.: protege-se as mulheres, a criança, os grupos étnicos minoritários, as vítimas de tortura, ...). Já o sistema geral de proteção (ex: Pactos da ONU de 1966) tem por endereçado toda e qualquer pessoa, concebida em sua abstração e generalidade (ninguém, todos,...). Vale dizer, torna-se insuficiente tratar o indivíduo de forma genérica, geral e abstrata. Torna-se necessário a especificação do sujeito de direito, que passa a ser visto em sua peculiaridade e particularidade. Nesta ótica determinados sujeitos de direitos, ou determinadas violações de direito exigem uma resposta específica, diferenciada. Neste cenário as mulheres devem ser vistas nas especificidades e peculiaridades de sua condição social. Importa o respeito à diferença $e$ à diversidade, o que lhes assegura um tratamento especial.” (grifos nossos).

Juridicamente, o princípio da igualdade é considerado sob dois aspectos: o da igualdade na lei e o da igualdade perante a lei. $O$ primeiro é exigência dirigida ao legislador, que ao elaborar as leis não poderá incluir elementos de discriminação. O segundo destina-se aos demais poderes estatais que aplicam as leis, pois após sua elaboração pelo legislativo, estas não poderão estar subordinadas a critérios arbitrários de tratamento seletivo ou discriminatório. (BRASIL, 1998).

Sobre o direito à igualdade, a CEDAW postula tanto a formal quanto a concreta. Em relação à concreta, dispõe sobre a adoção da discriminação positiva temporária:

Artigo $4^{\circ}$

1. A adoção pelos Estados-Partes de medidas especiais de caráter temporário destinadas a acelerar a igualdade de fato entre o homem e a mulher não se considerará discriminação na forma definida nesta Convenção, mas de nenhuma maneira implicará, como consequência, a manutenção de normas desiguais ou separadas; essas medidas cessarão quando os objetivos de igualdade de oportunidade e tratamento houverem sido alcançados.

2. A adoção pelos Estados-Partes de medidas especiais, inclusive as contidas na presente Convenção, destinadas a proteger a maternidade, não se considerará discriminatória. (BRASIL, 2002b:s.n.p.). (grifos nossos).

Assim, sob esse aspecto, a igualdade será: igualdade formal (a da lei), e igualdade material ou concreta (a perante a lei). Há suporte legal para que a mulher tenha tratamento diferenciado. Nessa perspectiva, é necessário entender porque os efeitos da igualdade de direitos para a mulher devem traduzir-se na adoção de instrumentos que viabilizem a igualdade concreta: as políticas públicas.

Até o século $\mathrm{XX}$ as leis brasileiras não adotavam o princípio da igualdade. Ratificavam a diferença de gênero entre homens e mulheres criando condições desiguais e de exclusão em relação a direitos: as mulheres precisavam de autorização do marido para trabalhar fora, não podiam votar, não podiam candidatar-se e não podiam praticar qualquer ato da vida civil. A desigualdade era consagrada como algo natural pela sociedade da época, que achava que as mulheres deveriam ser submissas e obedecer aos ditames dos maridos. (KAMIMURA et al, 2017, p. 72).

Todavia, acompanhando as mudanças sociais e de valores, posteriormente a legislação passou a adotar dispositivos que favoreceram as mulheres em seus direitos políticos, sociais, civis e trabalhistas. Especialmente após a promulgação da Constituição Federal de 1988, todos os códigos deveriam obedecer ao princípio da igualdade como fundamento.

Várias leis especiais e específicas como discriminação positiva foram promulgadas, para dar às mulheres igualdade de condições em proteção mais efetiva, por exemplo: a Lei n.9.504/1997 que determinou cotas para garantir maior participação das mulheres em candidaturas nas eleições; a Lei Maria da Penha, embora já houvesse dispositivo que criminalizasse a violência doméstica, foi necessária uma lei específica para proteger a mulher por causa do alto nível de violência que sofria, tornava desproporcional o grau de defesa e proteção e restringia o exercício de seus direitos. De igual modo a Lei do feminicídio, embora já houvesse a tutela da vida contra assassinatos, através do Código Penal Brasileiro, essa lei protege de forma específica as mulheres. 


\section{A VIOLAÇÃO DA IGUALDADE E DOS DIREITOS DA MULHER}

Os processos econômicos da globalização afetam profundamente a atuação do Estado, agravando a crise e acentuando os problemas sociais, uma vez que o fragiliza e impede de implementar políticas públicas. Consequentemente, os direitos humanos são diretamente influenciados, porque violados, ocasionando ainda mais desigualdades e vulnerabilidades.

Trazer à reflexão os meandros que envolvem a efetivação e aplicação dos direitos humanos e fundamentais para alcançar justiça social em uma sociedade, tem importância para compreender os significados explícitos e subliminares das ameaças e violações desses direitos em relação à mulher.

Uma das formas de violação dos direitos humanos, é salientada por Sen (2010, p. 33-4) como "exclusão como forma de privação":

Muitas privações e violações de direitos humanos de fato assumem a forma da exclusão de prerrogativas individuais elementares que deveriam ser dadas como certas [...]. Vários tipos de privação, que vão da violação dos direitos civis e políticos, [...] à destituição econômica e à falta de assistência médica e educação.

A respeito da exclusão por condições de desigualdades sociais e políticas da mulher, Mayor (2000, p. 366) ao citar Hannah Arendt, compara que excluir o "Outro" é roubar-lhe a dignidade, é não reconhecê-lo como membro de uma comunidade, despojá-lo de cidadania. Considera que a exclusão abre portas para discriminações, violências e perseguições. E completa que:

A luta contra a discriminação das mulheres obriga à sua participação plena e inteira na vida econômica, politica e cultural. Os direitos humanos são os direitos de toda a humanidade.

Portanto, pode-se considerar que as privações, além de originarem debilidades, são também formas de excluir porque trazem em si diversos aspectos de violação de direitos. De um lado porque não os oferece, e de outro porque o faz de modo injusto ou desfavorável. Configuram-se como exclusões múltiplas. Por certo, as mulheres estão nessa inclusão de excluídos, porque ainda não estão incluídas de forma justa e favorável em igualdade de direitos na sociedade.
Contudo, Sen (2010, p. 35) também enfatiza uma outra forma de violação dos direitos humanos como privação, que não perpassa pela exclusão. Tratase do que denomina de "inclusão injusta" e de "inclusão desfavorável": "grande parte dos problemas de privação surge de termos desfavoráveis de inclusão e de condições desfavoráveis de participação, e não do que se poderia chamar de um caso de exclusão". Assim considera as condições participativas desiguais, cujo foco imediato está na natureza desfavorável da inclusão envolvida. Para o autor continuam sendo exclusões ainda mais graves, pois mitigam a exclusão em formas de "incluir o excluído".

Segundo o autor, são exclusões por privações em situações veladas que incluem violações de direitos. É uma classe importante de privações que recebe uma atenção pequena, mas que possui um alcance massivo, atinge as classes sociais mais pobres. Envolve simultaneamente inclusões injustas e exclusões debilitantes (Idem, p.38).

Os efeitos da igualdade de direitos devem traduzir-se na adoção de instrumentos que viabilizem a igualdade concreta. A importância está na implementação dos direitos que garantem o exercício da cidadania, com base nas relações de gênero, nesse caso, as políticas públicas para a mulher.

A esse respeito, Gomes (2003, p. 65), comenta que as ideias que mudaram o estatuto legal das mulheres através da Constituição, precisam refletir os efeitos não apenas no papel:

A igualdade constitucional terá que ser implantada não apenas alterando toda a legislação infraconstitucional que a contrarie, mas, sobretudo, criando condições sociais, políticas e econômicas que viabilizam (sic!) a eficácia da lei. Há que se por em prática mecanismos específicos para se cumprir a imposição constitucional.

O que ainda acontece são condições que impedem essa concretização, consoante denuncia Krempel (2001, p.88):

Na prática, assistimos mulheres que não podem trabalhar por não terem onde deixar seus filhos, uma vez que faltam creches; outras que perdem o emprego ao levar o filho ao médico e ficar (sic!) por horas em uma fila do serviço público de saúde; falta de estudo dessas mulheres que acabam tornando-se desqualificadas para pleitear um emprego melhor e assim melhorar as condições de vida sua e de sua família. 
Sobre o que pode ser realizado para a implementação, Zimath (2004, p. 113-114), responde que uma possiblidade é a criação de instituições capazes de dar executabilidade aos preceitos que desenham o ordenamento jurídico, através de mobilização conjunta entre o Estado e a sociedade civil. Deve haver um programa político e social amplo, capaz de modificar as práticas sociais, uma vez que condutas se modificam e se transformam através da educação e de políticas públicas.

Compreende-se que os direitos conquistados pelas mulheres, e transformados em leis, somente acontecerão e se tornarão acessíveis para todas, mediante o oferecimento de condições efetivas para o seu exercício. Condições que podem ser dadas através de políticas públicas diretamente implementadas pelo Estado. Mas que também podem ser oportunizadas pela sociedade através de vários atores sociais, que se engajem na causa pela defesa da igualdade de direitos, em termos de gênero.

\section{O DIREITO FUNDAMENTAL À SAÚDE DA MULHER}

No campo da saúde, o direito também alcança a mulher de forma especial e específica para garantir a sua igualdade respeitando-se a sua diferença. No início, o direito à saúde da mulher baseava-se em questões biológicas, pelo fato de a reprodução humana acontecer no corpo da mulher. O direito consagrava e protegia apenas os direitos das mulheres decorrentes da reprodução: serviços de atenção pré-natal, parto, puerpério, prevenir a mortalidade materna etc. Em decorrência da característica reprodutiva, outros direitos passaram também a ter proteção: licença maternidade, amamentação etc. (KAMIMURA et al, 2017, p. 73).

Posteriormente outros direitos sem relação com o aspecto reprodutivo da mulher foram incorporados, mas ainda relacionados ao corpo, como por exemplo: prevenção contra o câncer de mama, útero e ovário. Mas pode-se também falar em direitos na área trabalhista, previdenciária e educacional. Embora ainda lutem para obter o direito à igualdade de remuneração, e para poderem dispor sobre o próprio corpo em relação ao aborto.

A partir dos relatórios do PNUD lançados pela ONU, com resultados de pesquisas sobre as condições das mulheres em vários países, e das Cartas das
Conferências da CSW, sugestões específicas sobre o direito à saúde da mulher tomaram uma conexão mais propicia à dimensão mais ampla do conceito de saúde. Isso se dá pelo entendimento de que, para que o desenvolvimento humano seja o alcançado, é necessário respeitar os direitos humanos.

Os relatórios e as Cartas começaram a apresentar parâmetros e prescrever ações de combate às desigualdades relacionadas à pobreza, autoritarismos e exclusões de diversas naturezas. Sob o enfoque dos direitos humanos delineava-se atingir as metas de desenvolvimento com democracia, liberdades e combate à pobreza e desigualdades de gênero.

A Carta da CEDAW (1979), é a grande referência dos indigitados enfoques, e a primeira a dispor amplamente sobre os direitos à saúde da mulher. O Conselho Nacional dos Direitos da Mulher (CNDM) foi criado em 1985, vinculado ao Ministério da Justiça, para promover políticas que visassem eliminar a discriminação contra a mulher e assegurar sua participação nas atividades políticas, econômicas e culturais do país. (<http://www.spm.gov.br>).

De 1985 a 2010, o CNDM teve suas funções e atribuições bastante alteradas. Em 2003, o Brasil criou a Secretaria Especial de Políticas para Mulheres da Presidência da República, diretamente subordinada à Presidência da República. Atualmente denomina-se Secretaria Nacional de Políticas para Mulheres (SPM), e foi transferida para o Ministério dos Direitos humanos. O CNDM passou a integrar a estrutura da SPM e a contar, em sua composição, com representantes da sociedade civil e do governo. Isso ampliou significativamente o processo de controle social sobre as políticas públicas para as mulheres. O CNDM tem como uma de suas importantes atribuições, apoiar a SPM em suas articulações com diversas instituições da Administração Pública Federal e com a sociedade civil. (<http://www.spm.gov.br $>$ ).

\section{POLÍTICAS PARA MULHERES}

De maneira específica, os modos de ser e de viver das mulheres são influenciados por determinantes sociais em vários âmbitos. Entre esses âmbitos está o da saúde. Nesse aspecto, a condição da mulher tem sido uma preocupação abordada em nível mundial por organizações internacionais humanitárias e de defesa dos direitos humanos, como a ONU. 
Os alertas sobre as condições de vida degradantes das mulheres em países desenvolvidos, subdesenvolvidos em desenvolvimento, bem como as sugestões de políticas públicas voltadas especialmente para atenção às mulheres tem sido tema de relatórios e campanhas. A partir dessas iniciativas muitos países têm se posicionado com políticas para o enfrentamento de tais adversidades.

O Brasil foi um dos pioneiros na América Latina em reconhecer a necessidade de atenção especial às condições da mulher, principalmente nas questões sobre a saúde. Em 1984 o governo federal lançou o Programa de Assistência Integral à Saúde da Mulher (PAISM), que posteriormente foi transformado na Política Nacional de Atenção Integral à Saúde da Mulher (PNAISM), importante conquista dos movimentos feministas pela igualdade de gênero.

Na PNAISM, a saúde é entendida como universal e integral, como uma ruptura conceitual de política e critérios de prioridades, para além das demandas da gravidez e do parto. Considera o campo dos direitos sexuais e reprodutivos, com ênfase na melhoria da atenção obstétrica, no planejamento familiar, na atenção ao abortamento inseguro e no combate à violência doméstica e sexual. Considera que a humanização e a qualidade da atenção em saúde são condições essenciais para que, a partir da saúde, a mulher obtenha a resolução dos problemas identificados, fortaleça-se frente a essas identificações, e tenha seus direitos reconhecidos e respeitados na promoção do autocuidado. (BRASIL/ PNAISM, 2009, p. 5-21).

Freitas et al (2009, p. 424-28), analisaram os pressupostos da promoção da saúde da PNAISM. Segundo esses pesquisadores, a PNAISM procurou em seus princípios e diretrizes estabelecer áreas prioritárias para a promoção e humanização da saúde a fim de minimizar as iniquidades existentes na saúde da mulher, enfatizando com isso, mulheres indígenas, lésbicas e presidiárias. Entretanto, ainda assim, o próprio sistema de saúde enfrenta dificuldades em atender à mulher em tais especificidades; percebe-se certa valorização da doença em parte das ações propostas. Na prática, a integralidade da assistência não é efetivamente contemplada, tendo em vista que o sistema de saúde apresenta dificuldades em assistir a mulher nas áreas específicas de climatério, infertilidade, saúde mental e saúde ocupacional.
Sob a responsabilidade da SPM, foram criadas as três versões do Plano Nacional de Políticas para Mulheres (PNPM), para promover a melhoria das condições de vida e saúde destas, em consonância com os requisitos da CEDAW.

As três versões do PNPM criadas em 2003, 2007 e 2013, possuem estratégias e ações específicas para: mundo do trabalho e autonomia econômica; educação; saúde integral, direitos sexuais e direitos reprodutivos; enfrentamento de violências; participação nos espaços de poder e desenvolvimento sustentável. (BRASIL/IPNPM, 2004, p. 9-31; BRASIL/IIPNPM, 2008, p. 17-27; BRASIL/IIIPNPM, 2013, p. 9-12). Esse Plano está em sua terceira versão, a caminho dos preparativos da quarta através dos resultados da Conferência Nacional de Políticas para as Mulheres, ocorrida em 2016.

Sob a perspectiva de conquistas e melhorias dos direito das mulheres, as três versões do PNPM são relevantes porque representam a promoção das mulheres sob a forma de política de combate à desigualdade de gênero.

Como preconizam promover a melhoria das condições de vida e saúde das mulheres, os PNPMs as visualizam em suas realidades carreadas de múltiplas necessidades (saúde, moradia, trabalho, educação e outros). O que requer políticas públicas articuladas com outros conhecimentos e setores, além dos que já acontecem na área da saúde.

O campo acadêmico e de pesquisas sociais também têm se interessado por discutir e apresentar contribuições para o desenvolvimento da temática e de sua práxis. Entre os estudiosos desses temas há os que defendem a adoção de políticas públicas voltadas para as diversidades como forma de reduzir as desigualdades e as vulnerabilidades (PINHEIRO et al, 2002; RIBEIRO, 2007).

Entretanto, há os que não defendem a adoção de tais políticas e tecem críticas às práticas do Estado e dos movimentos sociais que as defendem. Como exemplos, Assis e Jesus (2012, p. 2870) citam os seguintes comentários de Saito, Lacerda e Fracolli (2006), e Sorj (2004):

A proposição de políticas de saúde para grupos específicos gera polêmica por ser, a princípio, contrária à universalidade defendida na Carta Magna. "Verifica-se que importantes justificativas teóricas são impostas para a adequação dos serviços 
às demandas, porém o acesso à APS não deve lançar mão de nenhum método ou processo que eleja populações prioritárias, visto que, no sistema, esse nível é considerado a porta de entrada".

Sorj, contrariando tal expectativa, faz um alerta decisivo no balizamento de ações inclusivas: "a demanda de direitos realizada pelas novas identidades coletivas, quando associada a reivindicações distributivas, apresenta risco de despolitização e da erosão do espaço público, pois essas identidades questionam a política como produção de uma utopia comum e transformam o sistema de representação em um processo de agregação de interesses de fragmentos sociais".

Segundo as referidas autoras as maiores dificuldades devem-se ao grande desafio para o sistema de saúde a efetivar acesso equitativo, porque cada segmento social tem diferentes demandas produzidas por processos sociais de exclusão (como por exemplo, os horários de atendimento que não favorece as pessoas que trabalham, pois precisam faltar e pedir atestado). Essas demandas nem sempre são percebidas pelo poder público. E quando percebidas a gestão não tem acúmulo reflexivo, para formular políticas. Para grupos sociais organizados as dificuldades não são menos díspares, o atendimento de suas necessidades se dá após reivindicações e pressões sobre os governos. As autoras opinam que:

As políticas de saúde devem ser capazes de eliminar a barreira financeira entre os serviços e a comunidade, de enfrentar a mercantilização do setor saúde e a desproporção oferta/demanda existente; e construir uma rede de atenção regionalizada e hierarquizada que garanta o acesso universal, equitativo e integral. (ASSIS e JESUS, 2012, p. 2871).

Desse modo, é oportuno apontar trechos da reportagem de Machado (2017, p. 21), realizada com representantes de movimentos de mulheres na $2^{a}$ Conferência Nacional de Saúde das Mulheres (CNSMu), em agosto de 2017. Em suas falas as representantes deixam evidente o isolamento e a exclusão que muitas mulheres estão submetidas, e dimensionam os desafios para a efetivação de uma política de atenção integral à saúde das mulheres como um grupo composto também por diversidades e desigualdades.

Nessa conferência buscou-se o debate de ideias e práticas para o crescimento da força das mulheres.
Conforme relatam as representantes de movimentos e as delegadas da CNMu, a pluralidade das mulheres é uma grande questão que precisa ser evidenciada: "Hoje, não falamos mais da saúde da mulher, mas sim da saúde das mulheres." Para as representantes, "são mulheres que estão à margem da margem da sociedade, invisíveis a tantos outros grupos", a exemplo das moradoras de rua. A representante da União Brasileira de Mulheres (UBM), Carmem Lucia Luiz, avalia que: "só será possível trabalhar a equidade se conseguirmos ver onde estão as diferenças e quais dessas diferenças implicaram desigualdades." (MACHADO, 2017, p. 21;24).

Os argumentos apresentados demonstram que as reivindicações das mulheres, por políticas públicas voltadas para as suas necessidades, alcançam patamares de amadurecimento e evolução para questões mais amplas e abrangentes em novos direitos, e na inclusão de novos marcadores sociais de diferenças em prol da igualdade.

\section{CONSIDERAÇÕES FINAIS}

A atenção à mulher tem sido uma preocupação mundial. Preocupação essa tanto como forma de diminuir as desigualdades de gênero e garantir-lhe direitos, quanto de valorizá-la e empoderá-la como ator social capaz de realizar profundas transformações e melhorias sociais.

As diferenças sociais e econômicas, a violência, as desigualdades de gênero, a submissão às condições análogas à de escravo em relações de trabalho, a exploração sexual e outras condições e formas de submissão e aviltamento da mulher significam muito mais que falta de valorização do gênero por si só. Tais atos ferem diretamente em essência a dignidade da pessoa humana, portanto, representam graves violações aos direitos humanos. No caso do Brasil, tais atos e sua tolerância também ferem diretamente e em essência o Estado democrático de direito constitucionalmente estabelecido.

Essas condições ocasionam degradação e agravos à saúde das mulheres, que podem ser expressos não somente sob a forma de morbidades, mas também de mortalidades. Por tais aspectos, essas condições são um problema de saúde pública, merecem atenção especial e específica sob a concepção de direitos à saúde, e saúde das mulheres. 
Nesse sentido, da relação entre a saúde e os direitos humanos, sob a perspectiva dos direitos da mulher, pode-se destacar que:

a. os direitos humanos e o conceito ampliado de saúde possibilitam ver as questões e problemas sociais e culturais da mulher através do viés da saúde para combater as desigualdades e as violações de direitos;

b. a igualdade de direitos entre homem e mulher significa um novo arranjo de relações sociais, de forma coerente com a visão de desenvolvimento humano equitativo e sustentável;

c. a desigualdade de gênero não é mais uma questão ideológica, é uma violação dos direitos humanos das mulheres;

d. combater a discriminação contra a mulher, as desigualdades e a pobreza, significa defender seus direitos e dar-lhes oportunidades e capacidades para o desenvolvimento humano;

e. os direitos da mulher, os acessos e as ações que viabilizam o reconhecimento, gozo e fruição de tais direitos precisam ser com políticas oportunas e adequadas.

Certamente, a implementação de políticas públicas que levam à promoção das mulheres, sob a forma de política de combate à desigualdade de gênero, são importantes para determinar melhorias que as retirem da condição de vulnerabilidade em que se encontram. Todavia, sob a perspectiva de conquistas e melhorias dos direito das mulheres, é necessário ir além das estratégias de combate à desigualdade de gênero em aspectos gerais.

As versões dos PNPMs propostas e implementadas até então têm favorecido as mulheres como grupo homogêneo. Mas também é necessário alcançá-las como grupo composto por diversidades étnicas, sociais, econômicas, orientação sexual, faixa etária, condições de necessidades e degradações diferentes em tais diversidades. Políticas com estratégias e ações mais amplas e inclusivas, que propiciem: educação para a cidadania; desenvolvimento sustentável com igualdade econômica e social; cultura, comunicação e informação democráticas e não discriminatórias; enfrentamento de todas as formas de violência e discriminações contra as mulheres; e enfrentamento das desigualdades geracionais. Assim, as políticas públicas determinarão melhorias para que as mulheres consigam sair da situação de vulnerabilidade e desigualdades de gênero, em condições inclusivas para todas.
Defende-se a importância dos direitos da mulher e sua garantia como discriminação positiva, bem como a necessidade de implementação através de políticas públicas especiais e específicas, segundo categorias de direitos que alcancem as mulheres em sua diversidade.

Defender, proteger e promover os direitos humanos das mulheres é respeitá-las em sua dignidade como seres humanos livres, autônomos e iguais. A defesa dos direitos das mulheres fortalece os direitos fundamentais de todas as pessoas, porque como agentes catalizadores as mulheres fortalecem a defesa da democracia, as conquistas da cidadania e a justiça social.

\section{REFERÊNCIAS}

ALEMBERT, Z. A história da mulher. A mulher na história. Brasília: Fundação Astrogildo Pereira, FAP Abaré, 2004. Disponível em: https://issuu.com/abare.editorial/docs/a mulher_na_hist_ria_-_zuleikaala10jun2013 Acesso: março de 2018 .

AMARANTE, J. Luta pelos direitos das mulheres na Constituinte ficou conhecida como Lobby do Batom. Agência Brasil, 8 de março de 2008. Disponível em: http:// www.nominuto.com/noticias/brasil/luta-pelos-direitos-dasmulheres-na-constituinte-ficou-conhecida-como-lobby-dobatom/12927/ > . Acesso: março de 2018.

ASSIS, M. M. A.; JESUS, W. L. A. Acesso aos serviços de saúde: abordagens, conceitos, políticas e modelo de análise. Ciência e Saúde Coletiva. n.17, v. 11, 2012, p. 2865-2875.

ASSMANN, S. J. Declaração dos direitos da mulher e da cidadã. Revista Internacional Interdisciplinar Interthesis. Florianópolis, v.4, n.1, Jan/Jun. 2007, s.n.p.

BENEDICTIS, N. M. S. M. Memória e geografia social de mulheres em Rio de Contas - Bahia: a participação feminina no processo de organização de uma sociedade. Tese (doutorado mestrado em Memória: Linguagem e Sociedade). - Programa de Pós-Graduação em Memória: Linguagem e Sociedade Universidade Estadual do Sudoeste da Bahia, 2016. Orientadora Profa. Dra. Rita Maria Radl Philipp, Vitória da Conquista, 2016. Disponível em:

http://www2.uesb.br/ppg/ppgm1s/wp-content/ uploads/2017/06/Tese-Nereida-Maria-Mafra-de-Benedictis. pdf . Acesso: junho de 2018.

BRANDÃO, P. T. Ações constitucionais: novos direitos e acesso à justiça. Florianópolis: Habitus, 2001.

BRASIL. [Constituição (1988)]. Constituição da República Federativa do Brasil [recurso eletrônico]. Brasília : Câmara dos Deputados, Edições Câmara, 2016. - (Série textos básicos ; n. 113) . Disponível em: <http://www.camara.leg. br/editora $>$. Acesso em: agosto de 2016. 
BRASIL. Supremo Tribunal Federal. Informativo n.135. RDA 183/143, 07/12/1998.

BRASIL. Lei $n^{\circ}$ 8.080, de 19 de setembro de 1990. Lei orgânica da saúde. Disponível em: http://www.planalto.gov. br/ccivil_03/leis/L8080.htm . Acesso: janeiro de 2017.

BRASIL. [2002a]. Ministério da Saúde. Secretaria de Políticas de Saúde. Projeto Promoção da Saúde. As Cartas de Promoção da Saúde. Brasília: Ministério da Saúde, 2002. Disponível em: http://bvsms.saude.gov.br/bvs/publicacoes// cartas_promocao.pdf . Acesso: agosto de 2017.

BRASIL. [2002b]. Decreto $n^{\circ} 4.377$, de 13 de setembro de 2002. Presidência da República. Casa Civil. Subchefia para Assuntos Jurídicos. Convenção sobre a Eliminação de Todas as Formas de Discriminação contra a Mulher. Disponível em : http://www.planalto.gov.br/ccivil_03/decreto/2002/d4377. htm . Acesso: setembro de 2017.

BRASIL. Lei n. 13.104, de 9 de março de 2015. Legislação Informatizada. Publicação Original. Disponível em: http:// www2.camara.leg.br/legin/fed/lei/2015/lei-13104-9-marco2015-780225-publicacaooriginal-146279-pl.html . Acesso: março de 2018.

BRASIL. Ministério da Saúde. Secretaria de Atenção à Saúde. Departamento de Ações Programáticas Estratégicas. Política nacional de atenção integral à saúde da mulher: princípios e diretrizes / Ministério da Saúde, Secretaria de Atenção à Saúde, Departamento de Ações Programáticas Estratégicas. - Brasília : Editora do Ministério da Saúde, 2009. Disponível em: http://bvsms.saude.gov.br/bvs/ publicacoes/politica_nac_atencao_mulher.pdf . Acesso: setembro de 2017.

BRASIL. Presidência da República. Secretaria de Políticas para as Mulheres. I Plano Nacional de Politicas para as Mulheres. Brasília: Secretaria de Políticas para as Mulheres, 2004. Disponível em: http://www.spm.gov.br/assuntos/ pnpm/publicacoes/pnpm-2013-2015-em2ago13.pdf Acesso: setembro de 2017.

BRASIL. Presidência da República. Secretaria de Políticas para as Mulheres. II Plano Nacional de Politicas para as Mulheres. Brasília: Secretaria de Políticas para as Mulheres, 2008. Disponível em: http://www.spm.gov.br/assuntos/ pnpm/publicacoes/pnpm-2013-2015-em-ago13.pdf

Acesso: setembro de 2017.

BRASIL. Presidência da República. Secretaria de Políticas para as Mulheres. III Plano Nacional de Políticas para as Mulheres. Brasília: Secretaria de Políticas para as Mulheres, 2013. Disponível em: http://www.spm.gov.br/assuntos/ pnpm/publicacoes/pnpm-2013-2015-em-ago13.pdf. Acesso: setembro de 2017.

BRASIL. Secretária Especial de Politicas para Mulheres (SPM). Disponível em: http://www.spm.gov.br . Acesso: setembro de 2017.
COSTA, A. O. SUR. Revista Internacional de Direitos Humanos / Associação Direitos Humanos em Rede, v.13, n.24, São Paulo, dez. 2016. Disponível em: http://sur. conectas.org/wp-content/uploads/2017/02/sur-24-porcompleto.pdf Acesso: março de 2018.

DA SILVA, S. M. A carta que elas escreveram: a participação das mulheres no processo de elaboração da Constituição Federal de 1988. Tese (doutorado). Universidade Federal da Bahia. Faculdade de Filosofia e Ciências Humanas. Salvador -BA, 2011. Disponível em: https://repositorio.ufba.br/ri/ handle/ri/7298. Acesso: março de 2018.

DINIZ, M. H. Dicionário Jurídico. São Paulo: Saraiva, 1998.

DINIZ, M. H. Dicionário Jurídico Universitário. São Paulo: Saraiva, 2010.

FREITAS, G.L.; VASCONCELOS, C.T.M; MOURA, E.R.F.; PINHEIRO, A.K.B. Discutindo a política de atenção à saúde da mulher no contexto da promoção da saúde. Rev. Eletr. Enf. [Internet]. v.11, n2, p. 424-8, 2009. Disponível em: http://www.fen.ufg.br/revista/v11/n2/v11n2a26.htm . Acesso em: novembro de 2017.

GOMES, R. R. Os novos direitos na perspectiva feminina: constitucionalização dos direitos das mulheres. In: WOLKMER, A. C.; LEITE, J. R. M. (Orgs.). Os novos direitos no Brasil: natureza e perspectivas. São Paulo: Saraiva, 2003.

HASENBALG, C. ; SILVA, N. V. Origens e destinos: desigualdades sociais ao longo da vida. Rio de Janeiro: IUPERJ/UCAM/Topbooks/FAPERJ, 2003.

INSTITUTO BRASILEIRO DE GEOGRAFIA E ESTATÍSTICA (IBGE). Estatísticas de Gênero: indicadores sociais das mulheres no Brasil. Estudos e Pesquisas Informação Demográfica e Socioeconômica, n.38. Disponível em: https://biblioteca.ibge.gov.br/visualizacao/ livros/liv101551_informativo.pdf . Acesso: março de 2018.

KAMIMURA, A. et al. Direitos humanos e vida cotidiana. Rio de Janeiro: Editora FGV, 2017.

KREMPEL, L. M. O acesso das mulheres à justiça. Cadernos Themis: gênero e direito. Porto Alegre: Themis Assessoria jurídica e estudos de gênero. N. 2, ano II, 2001.

MACHADO, O. M. Mulher: códigos legais e códigos sociais - o papel dos direitos e os direitos de papel. In: HESKETH, M. A. I. Cidadania da mulher: uma questão de justiça. Brasília: OAB Editora, 2003.

MACHADO, K. Desigualdades que afetam as mulheres de diferentes matizes. Rio de Janeiro: EPSJV-Fiocruz, ano X, n.53, p. 21-26, Set./Out. 2017.

MAYOR, F. Que futuro para os direitos do homem? In: AAVV. As Chaves do Século XXI. Lisboa: Editora Piaget/ UNESCO, 2000. 
MELO, M. Assédio sexual: um caso de inconstitucionalidade por omissão. Brasília. Revista de informação legislativa, v. 36, n. 143, p. 85-99, jul./set. 1999. Disponível em: http:// www2.senado.leg.br/bdsf/handle/id/508 . Acesso: maio 2018.

ORGANIZAÇÃO DAS NAÇÕES UNIDAS - ONU. Declaração Universal dos Direitos Humanos. 10 dezembro de 1948. Disponível em: <http://www. dudh.org.br/ declaracao >. Acesso: março de 2016.

ORGANIZAÇÃO DAS NAÇÕES UNIDAS - ONU (1986). Declaração sobre o Direito ao Desenvolvimento. Resolução n. ${ }^{\circ}$ 41/128 da Assembléia Geral das Nações Unidas, de 4 de dezembro de 1986. Disponível em: < http://www.direitoshumanos.usp.br/index.php/Direitoao-esenvolvimento/declaracao-sobre-o-direito-aodesenvolvimento.html . Acesso: maio de 2018.

ORGANIZAÇÃO DAS NAÇÕES UNIDAS - ONU MULHERES (2013a). Declaração e Programa de Ação de Viena (1993). Disponível em: http://www.onumulheres.org. br/wp-content/uploads/2013/03/declaracao_viena.pdf .

Acesso: maio de 2018.

ORGANIZAÇÃO DAS NAÇÕES UNIDAS - ONU MULHERES (2013b). Declaração e Plataforma de Ação de Pequim (1995). Disponível em: http://www.onumulheres. org.br/wp-content/uploads/2013/03/declaracao_beijing.pd Acesso: maio de 2018.

ORGANIZAÇÃO DAS NAÇÕES UNIDAS - ONU MULHERES (2013c). Convenção Interamericana para Prevenir, Punir e Erradicar a Violência Contra a Mulher "Convenção de Belém do Pará" (1994). Disponível em: http:// www.onumulheres.org.br/wp-content/uploads/2013/03/ convencaobelem1994.pdf. Acesso: março de 2018.

ORGANIZAÇÃO DAS NAÇÕES UNIDAS - ONU MULHERES (2018). Conclusões Acordadas na $62^{a}$ Sessão da Comissão da ONU sobre a Situação das Mulheres. Disponível em: <http://www.onumulheres.org.br/noticias/ direitos-das-mulheres-rurais-diversidade-etnica-e-fim-daviolencia-sao-contribuicoes-do-brasil-ao-documento-finalda-csw-62/ > . Acesso: maio de 2018.

ORGANIZAÇÃO DAS NAÇÕES UNIDAS no BRASIL - ONUBrasil. Direitos Humanos das Mulheres: a equipe das Nações Unidas no Brasil. Julho 2018. Disponível em: $<\quad$ https://nacoesunidas.org/wp-content/uploads/2018/08/ Position-Paper-Direitos-Humanos-das-Mulheres.pdf $>$. Acesso: agosto de 2018.

PENA, M. V. J; CORREIA, M. C. A questão de gênero no Brasil. In: Relatório CEPIA. Rio de Janeiro, 2003. Disponível em: $\quad<$ http://cepia.org.br/wp-content/uploads/2003/11/ questao_de_genero.pdf $>$. Acesso: março de 2018.

PINHEIRO, R. S. et al. Gênero, morbidade, acesso e utilização de serviços de saúde no Brasil. Ciência \& Saúde Coletiva, v.7, n.4, 2002, p.687-707.
PINSKY, C. B.; PEDRO, J. M. Igualdade e especificidade. In: PINSK, J.; PINSK, C. B. (Orgs.). História da cidadania. São Paulo: Contexto, 2003.

PINTANGUY, J. As mulheres e a Constituição de 1988. CEPIA.ORG. 2008. Disponível em: <http:// www.cepia.org. br/images/nov089.pdf $>$. Acesso em: junho dee 2018.

PIOVESAN, F. Direitos da Mulher na Sociedade Contemporânea. mimeo. In: SILVA, Marlise Vinagre. Violência contra a mulher: quem mete a colher?. São Paulo: Cortez Editora, 1992.

RIBEIRO, P. T. Direito à saúde: integridade, diversidade e territorialidade. Ciência \& Saúde Coletiva, v.12, n.6, 2007, p.1525-1532. Disponível em: http://www. scielo.br/scielo.php? script $=$ sci_arttext\&pid $=\mathrm{S} 1413$ 81232007000600014\&lang=pt. http://dx.doi.org/10.1590/ S1413-81232007000600014.Acesso: outubro de 2017.

SANTOS, B. S. Reconhecer para libertar: os caminhos do cosmopolitanismo multicultural. Rio de Janeiro: Civilização Brasileira, 2003.

SEN, A. K. Desenvolvimento como liberdade. Tradução Laura Teixeira Motta. São

SOARES, M.E.P.; ANDRADE, R. S. O. L. M. et al. A influência dos movimentos feministas na formulação do princípio fundamental de igualdade previsto na Constituição de 88. Revista Jus Navigandi, setembro de 2016. Disponível em: < https://jus.com.br/artigos/51966/a-influencia-dosmovimentos-feministas-na-formulacao-do-principiofundamental-de-igualdade-previsto-na-constituicao-de-88>. Acesso: março de 2018.

SOUZA, M. C. A Convenção sobre a Eliminação de todas as Formas de Discriminação contra as Mulheres e suas implicações para o direito brasileiro. Revista Eletrônica de Direito Internacional, v. 5, 2009, p. 346-386. Disponível em:

http://centrodireitointernacional.com.br/static/ revistaeletronica/volume5/arquivos_pdf/sumario/mercia cardoso.pdf>. Acesso: maio de 2018.

STEINMETZ, W. A. Colisão de direitos fundamentais e princípio da proporcionalidade. Porto Alegre: Livraria do advogado, 2001.

TOHIDI, N. Direitos das mulheres e movimentos feministas no Irã. SUR. Revista Internacional de Direitos Humanos / Associação Direitos Humanos em Rede, v.13 n.24, p.75 - 89, 2016. Disponível em: < http://sur.conectas.org/wp-content/ uploads>. Acesso: março de 2018.

VADE MECUM. Obra coletiva. 5. ed. rev., ampl. e atual. São Paulo: Editora Revista dos Tribunais, 2013.

ZIMATH, M. L. M. O fenômeno da geração de novos direitos e as relações de gênero. In: OLIVEIRA, A. B.; PASOLD, C. L. Teoria jurídica das relações interpessoais. Florianópolis (SC): Momento Atual, 2004. 